\title{
Evaluation of the impact of selected environmental aspects on the shaping of the land market on the example of the Wieliczka commune
}

\author{
Pawet Hanus ${ }^{1}$, and Elżbieta Jasińska ${ }^{1, *}$ \\ ${ }^{1}$ AGH University of Science and Technology in Kraków, Faculty of Mining Surveying and Environmental Engineering, Department of \\ Geomatics, al. Mickiewicza 30, 30-059 Kraków, Poland
}

\begin{abstract}
The land market is usually influenced by many factors, but the key to some of them is decisive when buying a property. These are both physical features of the property, such as the area, shape or class of the land as well as external factors related to the popularity of the area or the availability of communication. The group of factors that decide about the purchase is certainly the vulnerability of land to natural phenomena related to mass movements. They belong to factors that have a very negative impact on the price of real estate, limiting the possibility of its use, and above all buildings. In a situation where data on mass movements are available in a given area, these data directly affect the provisions of the study of conditions and directions of spatial development of the commune and, as a consequence, also local plans. The article analyzes the impact of landslide areas on property prices. The research was carried out in the municipality of Wieliczka where in 2008 a comprehensive assessment of mass movements was carried out, defining their character and making their classification.
\end{abstract}

\section{Introduction}

Landslides are one of the elements of the environment that negatively affect the use of land [1] For this reason, landslides have limited usefulness for investment purposes and often also for agricultural purposes. The landslide is, therefore, a form resulting from gravitational movements, causing a rapid displacement of rock masses in the direction of the force of gravity, as a result of which the material on the slopes is moved from the higher parts to the lower. The speed of movement is a relative term from a few minutes to a dozen or so days and longer [2, 3, 4]. It is one of the kinds of mass movement type, consisting in moving the rock or waste material along the surface of the slip (on which the bevel occurred), combined with the rotation. Such movement occurs under the influence of gravity $[5,6]$.

Disclosure of landslide areas in planning documentation is the result of the provisions of the 2003 Spatial Planning and Development Act [7]. The act stipulates that spatial planning should take into account, inter alia, the requirements of health protection and the safety of people and property. This provision introduces planning documentation, including in particular local spatial development plans (SPP) and a study of the conditions and directions of spatial development of the commune (SUiKZP) areas of landslides masses. It is an obligatory element of the Local Development Plan $[8,9]$

The landslide areas are, therefore, an element that will, along with others, affect the value of the property, being one of the key factors in determining the land use in
SUiKZP (polish abbreviation for Study Of Conditions And Directions Of Spatial Development) and MPDP (polis abbrevation for Local Development Plan). As a negative factor it will reduce the value of the property.

The article analyzes the value of registered plots located in landslide areas and in their immediate vicinity. The values of these plots were compared with similar plots, located outside the area of landslides.

\section{Analysis area}

The research area covers the area of the city of Wieliczka and adjacent villages. Wieliczka is a poviat town located in the Kraków agglomeration, about 14 km from Krakow. The city is located in a valley between two ridges of hills stretching from the west to the east: from the south of the Wieliczka Foothills, to the north from the Bogucice Sandstones forming part of the Wieliczka-Gdowska Upland. It is the intersection between the outer Carpathians and the Carpathian Foredeep. This location creates in the region of the city and commune natural terrain forms associated with the dislocations of land and rock, i.e. landslides. Plots located in mentioned area were compared with similar plots located outside the landslide area. Polish Geological Institute in the explanations to the geo-environmental map of Poland (Wieliczka sheet [10, 11]) stated that areas for which no buildings [12] should be erected were active landslides and areas of mining damage occurred. The former occur mainly in the areas south and southeast of Wieliczka. The distribution of

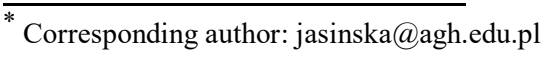


landslides in the neighborhood city of Wieliczka is shown in Figure 1.

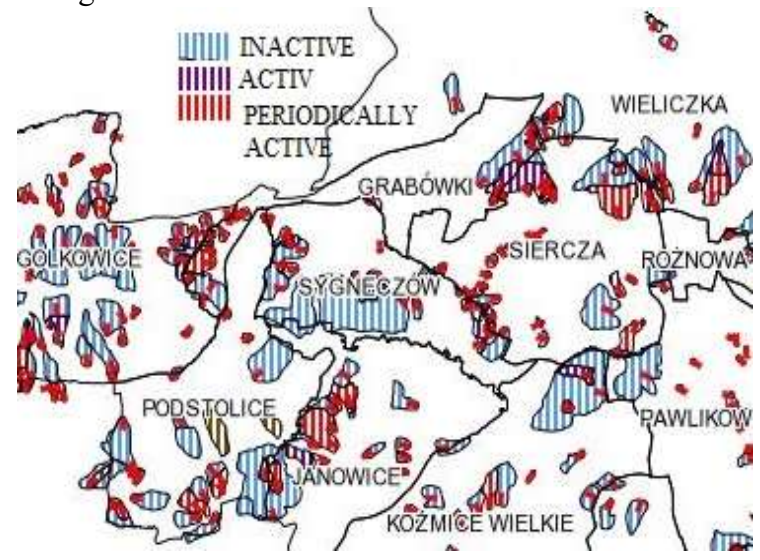

Fig. 1. Location of landslides in the city of Wieliczka [10]

In the local plan of the city and the commune of Wieliczka, they were divided according to the degree of activity in accordance [7]. For this reason, landslides can be distinguished [10]:

- active - a landslide that is in constant motion, or one whose activity symptoms occurred during registration or when the movement took place in the last 5 years,

- periodically active - a landslide within which the symptoms of activity have occurred at irregular intervals during the last 5-20 years,

- inactive - a landslide within which no symptoms of activity have been observed or documented during the last 20 years (stabilized).

The total area of landslides in the city of Wieliczka is 89.4 ha. According to research from 2008, 28.7 ha are active landslides $(32.1 \%), 8.4$ ha landslides active periodically $(9.4 \%)$ and 52.3 ha landslides $(58.5 \%)$.

Taking into account the requirements of the already mentioned act on planning and spatial development, most landslide areas were designated for non-investment purposes $[12,13]$. Nevertheless, some areas are feasible for investments, but this option is delineated as limited. However, this applies almost exclusively to inactive landslides. The detailed purpose of areas covered by inactive landslides is shown in Figure 2.

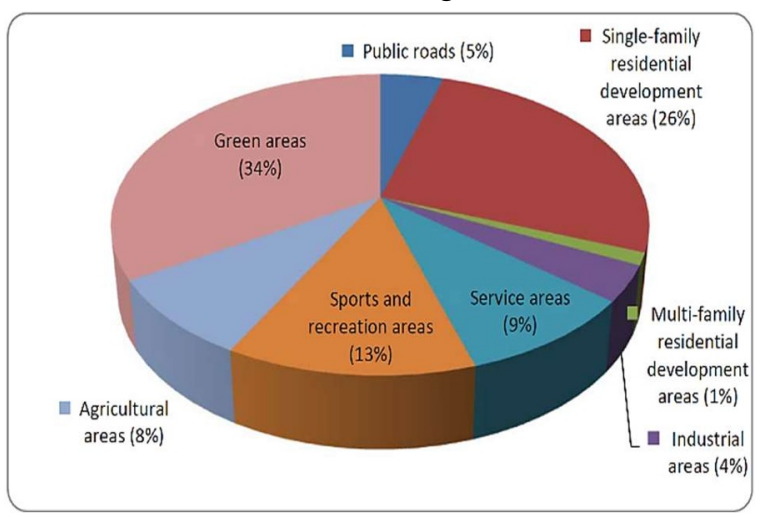

Fig. 2. Use of areas with identified inactive landslides [1]

Areas for housing purposes with limited development due to landslides areas were marked MNO - single-family housing construction, MWO - multi-family housing construction and UO - services ( presented as half-circle mark). Such areas are shown in Figure 3.

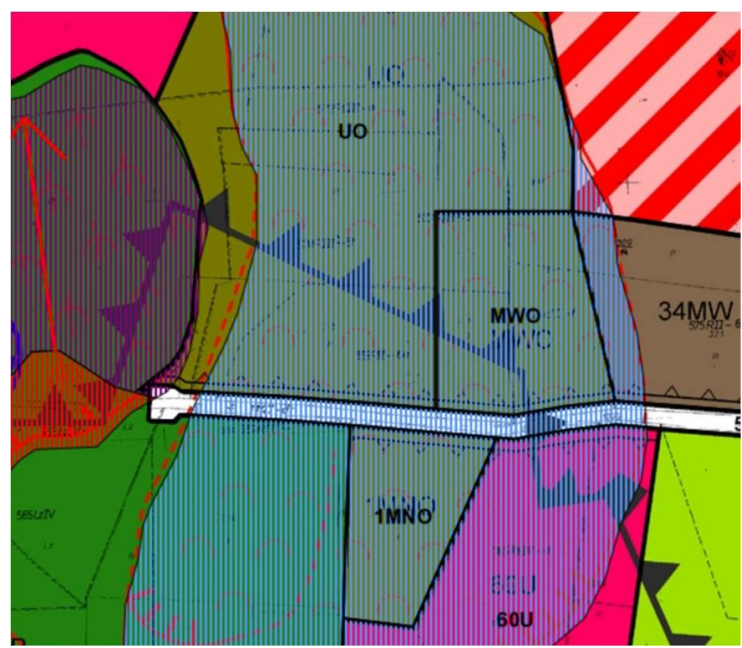

Fig. 3. Example of markings of areas limited by landslides in the city of Wieliczka [10]

For areas with limited development, the provisions of the Local Development Plan (LDP) require the location of facilities only on the condition that geological and engineering documentation is made, confirming that the proposed investment will not affect the soil balance and will not cause the landslide to become active. Additionally, in these areas, the building area is limited by a buffer of 10-20 meters, protecting the top or bottom of the scale.

At this point, it should be noted that the preparation of geological engineering documentation requires field research carried out by authorized persons. The geological information card constituting one of the documentation elements should include, among others, the number and depth of drillings performed, the number of courts, the location of test wells in the state coordinate system, and piezometric and dilatometric parameters of the soil [13]. Such a decision is unique, which is confirmed by the judgments of the case, issued by the supreme court

The documentation must also specify security recommendations for the buildings being designed [10]. Each time, therefore, the conditions for the implementation of the investment, in particular the minimization of the impact of landslides and the protection of the building in connection with the landslide, are individually determined in the geological engineering documentation. Therefore, the investor is not sure whether the investment will be economically justified until such documentation is prepared.[16]

\section{Analyzes carried out}

\subsection{Analysis of the real estate market in the commune of Wieliczka}

The scope of research and analyzes was carried out on the basis of 1251 transactions of undeveloped land property located in the Wieliczka Commune. The area is divided into the City of Wieliczka (Wieliczka precinct 1, 
Wieliczka precinct 2 and Wieliczka precinct 3) and the commune Wieliczka, which consists of 29 precincts (Brzegi, Grabie, Kokotów, Węgrzce Wielkie, Czarnochowice, Śledziejowice, Strumiany, Mała Wieś, Zabawa, Sułków, Lednica Górna, Rożnów, Mietniów, Grabówki, Siercza, Pawlikowice, Chorągwica, Golkowice, Sygneczów, Podstolice, Janowice, Koźmice Małe, Koźmice Wielkie, Raciborsko, Byszyce, Gorzków, Jankówka, Grajów, and Dobranowice). The data was obtained from the Poviat Eldership in Wieliczka and contain information about the sale of these properties in the period from January 2011 to October 2017. Below (Figure 4) is a map showing the average unit price of real estate in the studied area.

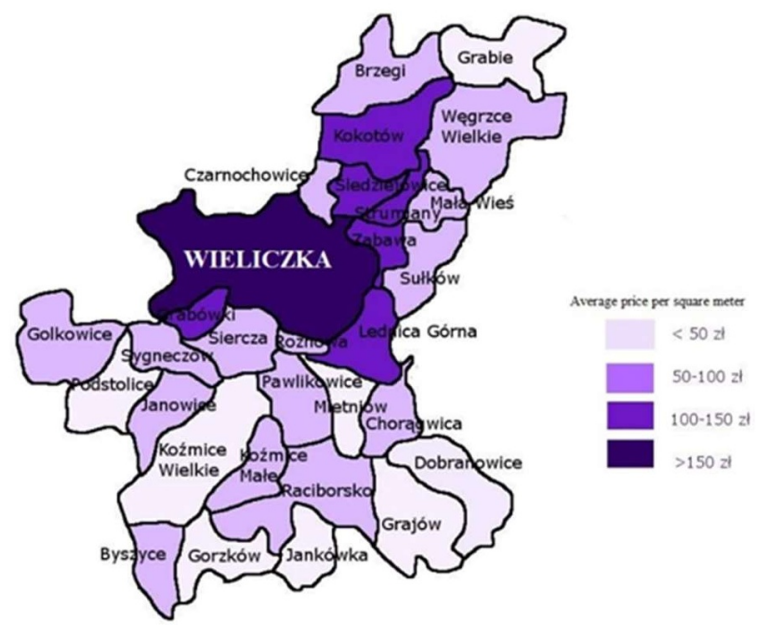

Fig. 4 Average prices of $1 \mathrm{~m}^{2}$ of land in the Wieliczka commune for land properties with an area larger than 3 ares

The key in this case will be the prices of real estate belonging to the landslide zone, as they cannot be builtup, thus their value is small, which proportionally translates into small losses. It is also worth considering properties that are "in the vicinity" of areas classified as landslides.

\subsection{Criteria for selecting the analyzed cases}

Real estate, which in recent years has been the object of trading on the real estate market, was selected for the analyzes. Selected plots can be divided into three groups:

- The first group consists of plots located in landslide areas. These landslips were closed landslides marked with LDP Wieliczka, as ON.

- The second group of analyzed plots are plots lying in the immediate vicinity of landslides, up to $100 \mathrm{~m}$, with no restrictions on the way of their destination in relation to the proximity of landslides. Here, it can be not only the expanding range of such a landslide that threatens the building, but also the destruction of the road leading to the property.

- The third group are plots beyond landslide areas at a distance of at least $300 \mathrm{~m}$ from the nearest landslide, and at the same time similar in terms of location and other parameters to plots from the first two groups.

\subsection{Analysis of the change in the value of real estate located in Raciborsko}

The first analyzed example concerns the case described in [15], it is a registered plots no. 127/1, located in Raciborsko, Wieliczka commune. The plot is located on the southern slope of the hill. The publication presents the geological aspect of the expansion of the landslide area, as a result of unfavorable climatic conditions - exactly intense rainfall in 2010 [17]. Analyzing the local plan for the selected area, it can be immediately noticed that there is no MNO symbol in its vicinity (Figure 5), although the local plan established in 2016, classifies the plot, $127 / 1$ as a landslide area of periodically active.

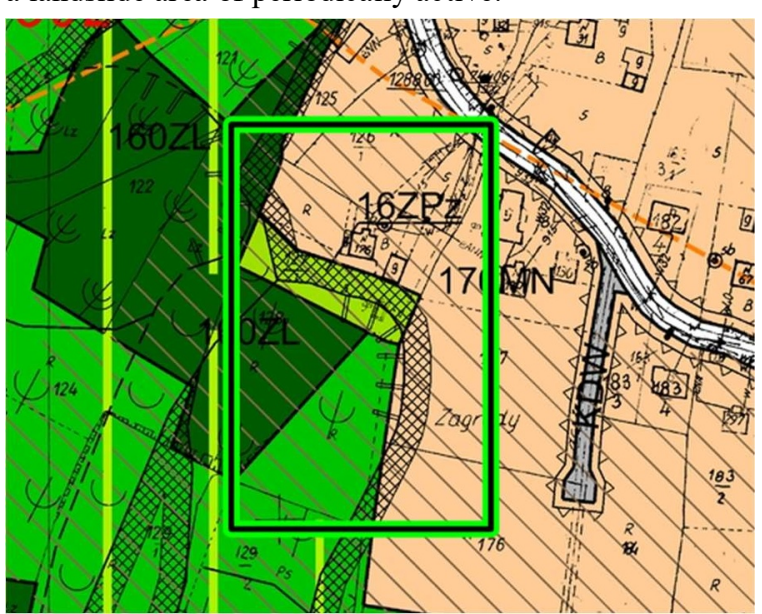

Fig. 5 Placement of the plot in the local plan [18]

An important element of this study is the occurrence of a soil continuity violation at a distance of $14 \mathrm{~m}$ from the south-west corner of a residential house (neighboring plots are built up), and the discharge was $0.5-0.7 \mathrm{~m}$. The landslide located south of the dwelling house had an area about 0.5 ha, it covered the eastern part of the neighboring plot, no. 128 and almost the entire southern part of plot 127/1. [15]

Authors of the study [19] clearly emphasize that the landslide was active also after the rainfall had finished and eventually covered its area of 5 hectares, reaching from the public road and threatening neighboring areas.

This situation evidently affects the value of the real property and neighboring properties by carrying out due diligence of such a property [4], this fact cannot be ignored and a pessimistic scenario should be assumed exclusion of buildings in this area.

In order to empirically examine the financial consequences of the situation, an estimate was made of the property constituting plot $127 / 1$ for two variants:

- The land property for low-rise single-family housing (not affected by a landslide)

- The land property for non-residential purposes, eg agricultural land - the current function of the plot. 
The following features can be attributed to the plot being valued:

- Area - 0.5626 ha

- Attractiveness of locations - medium (0)

- Neighborhood and surroundings - medium (2)

- Technical infrastructure - good (2)

- Shape and size of the plot - good (2)

- The proximity of landslides - direct contact (0)

- Destination in LDP (polish abbreviation MPZP) very good (2) - (MN) or bad (0) - agricultural areas.

The analysis collected information on 18 land properties ( 5 designated in the local plan for agricultural land, and 13 marked as MN single-family housing). These properties have been subject to market transactions in the last 15 months. The real estate being the subject of the right of ownership was selected for the valuation. Unit transaction prices range from $3 \mathrm{PLN} / \mathrm{m}^{2}$ to $9 \mathrm{PLN} / \mathrm{m}^{2}$ in the first case and from $10 \mathrm{PLN} / \mathrm{m}^{2}$ to $129 \mathrm{PLN} / \mathrm{m}^{2}$ in the second case. Even after these discrepancies you can see a huge difference in the prices of these properties.

The similarity of selected real estate to the valued property was formulated using the 7 attributes mentioned in the previous paragraph. On the basis of the analysis of the market of similar land properties to the valued property and based on the calculations according to the pairwise comparison method, the market value of the valued property is 23,658 PLN (for the purpose of agricultural land) and 142900 PLN (assuming the purpose in the local plan $\mathrm{MN}$ and distance from a landslide, up to 150), if the distance to an active landslide is increased above $300 \mathrm{~m}$, then the value of the property will increase to 700,000 PLN for the analyzed area.

Agricultural properties have always been cheap [20, $21,22,13]$ however, in the case of the analyzed case the key is the occurrence of a landslide, because this prevents the development that occurs on neighboring plots. The distance from landslides also played a key role here [12]. Based on the property sales data in this town (Figure 4), unit prices from 50-100 PLN $/ \mathrm{m}^{2}$ can be noted, while the current (most pessimistic) scenario for plot 127/1 allows estimation of its value at $4.21 \mathrm{PLN} / \mathrm{m}^{2}$, and the rational option - the option of development - allows a valuation of $25 \mathrm{PLN} / \mathrm{m} 2$. These are rates much lower than the average in the area, only the $300 \mathrm{~m}$ buffer from the nearest landslide guarantees obtaining average values (or) higher than the average for a given area.

\subsection{Real estate prices for the Wieliczka city}

The next examined case concerns the city of Wieliczka itself, in particular of zone 1. It is possible to notice here the full range of properties that are traded, both on green areas, unmanaged, as well as on residential areas of single- and multi-family housing with restrictions. In this case, the local plan was adopted in 2010 and any buildings in active and periodically active landslies were banned. Areas of inactive landslides can be built under the condition of obtaining a positive geological opinion. In addition, the construction index of such a plot was introduced at the maximum level of $30 \%$ [23]. The areas of periodically active landslides were allocated to urban greenery. [18]

This allows greater protection of landslides, and protects the local community against potential losses. The table below presents unit prices and dates of transactions for real properties located in diversified zones that have been traded in the last 5 years.

Table 1. Transaction prices of selected properties and their characteristics in terms of distance from landslide areas and destination in the local plan

\begin{tabular}{|c|c|c|c|}
\hline Plot ID & $\begin{array}{l}\text { Unit price } \\
{\left[\mathrm{PLN} / \mathbf{m}^{2}\right]}\end{array}$ & $\begin{array}{l}\text { Landslide } \\
\text { area or } \\
\text { distance } \\
\text { to it }\end{array}$ & $\begin{array}{l}\text { Design } \\
\text { ation } \\
\text { in } \\
\text { LDP } \\
\end{array}$ \\
\hline 121905_4.0001.1720/1 & 18 & $<5 \mathrm{~m}$ & $\mathrm{MN}$ \\
\hline 121905_4.0001.1199 & 18 & YES & MNO \\
\hline $121905 \_4.0001 .315$ & 51 & YES & $\mathrm{UO}$ \\
\hline 121905_4.0001.1032/8 & 19 & YES & $\bar{Z}$ \\
\hline 121905_4.0001.1065/2 & 82 & YES & MNO \\
\hline 121905_4.0001.1585 & 62 & $>30 \mathrm{~m}$ & $\mathrm{MN}$ \\
\hline 121905_4.0001.1147/3 & 212 & $>90 \mathrm{~m}$ & $\mathrm{MN}$ \\
\hline 121905_4.0001.1268 & 188 & $>15 \mathrm{~m}$ & MN \\
\hline 121905_4.0001.1668 & 65 & $>120 \mathrm{~m}$ & $\mathrm{MN}$ \\
\hline
\end{tabular}

Based on the analysis of the collected data, the results of which are presented in Table 1, the following conclusions can be made:

- The city of Wieliczka quickly secured itself against possible construction contractors resulting from the development of landslide areas by introducing appropriate entries into the local plan. The manifestation of this is the prohibition of development of active areas and the introduction of urban green areas on the majority of inactive landslides.

- Unit prices of land properties located in non-active areas, however with limited development, are however much lower than the average value for this area (above $150 \mathrm{PLN} / \mathrm{m}^{2}$ )

- The most expensive land properties are located at a considerable distance to hazardous areas, or are protected by additional earth structures.

- An interesting case is plot No. 121905_4.0001.1065/2, which in table 1 is with the unit price obtained in 2014, but it should be noted that it was also traded in 2011, then its unit price was 9 times higher - it was worth note this fact as the loss of property located just in the inactive landslide.

\section{Conclusions}

Analyzing the Wieliczka real estate market, one can notice a significant decline in the value of real estate located in areas with limited investment potential due to possible landslides. The difference in value may amount 
to as much as $80 \%$ (an example of a midwife's real estate in Raciborsko).

Such events will, however, concern rural areas for which prevention against the effects of landslides is not carried out and there are no Local Spatial Development Plans. The key in this case is to conduct a proper analysis of such areas, not only in legal terms, but also geological, which is confirmed by the example presented. It is difficult because in the presented example the landslide was activated due to the weather anomaly.

The presented geological analysis revealed the occurrence of a slip area of only 14 meters to the wall of a residential house. It was a previously unrecognized area, as an active area and only intense rains caused a change in the behavior towards the situation. In the same year, the town of Wieliczka had a local plan prepared, based on analyzes carried out in 2008. In extremely difficult situation may be found owners who will learn about the geological problems after purchasing real estate - then one should expect such a property to return to the market, probably with a lower price. An additional limitation is the issue of the development of such a property - a much smaller building area and the inclusion of additional restrictions resulting from geological expertise.

SOPO project [24] and the possibility of verifying data about real estate, but the awareness of such analysis and the necessity to monitor changes in cases of intense rainfall is definitely a valuable solution for protecting potential buyers.

\section{Acknowledgement}

Publication supported by the Polish Ministry of Science and Higher Education as a part of the program of activities disseminating science from the project „Organization of the First International Science Conference - Ecological and Environmental Engineering”, 26-29 June 2018, Kraków.

This work was carried out within the statutory studies of the AGH University of Science and Technology. Faculty of Mining Surveying and Environmental Engineering. Department of Geomatics No. 11.11.150.006.

\section{References}

1. J. Bydłosz, P. Hanus. Real Estate Management and Valuation, vol. 21, no. 4, pp. 5-10. (2013).

2. D. Cruden, A simple definition of a landslide. Bulletin of the International Association of Engineering Geology - Bulletin de l'Association Internationale de Géologie de l'Ingénieur. 43

3. J. Gocał, et al. "Determination of displacement and vibrations of engineering structures using groundbased radar interferometry." AGH University of Science and Technology Press, Kraków (2013).

4. E. Jasińska, E. Preweda. Effect the accuracy of benchmarks to establish of the determination of geodetic network. In: the 9th International
Conference Environmental Engineering : May 2223, 2014, Vilnius, Lithuania : selected papers (2014)

5. A. Szafarczyk, E. Puniach. Infrastruktura i Ekologia Terenów Wiejskich Nr 4, p.141-150 (2011).

6. L1. Vranken, P. Van Turnhout, M. Van Den Eeckhaut, L. Vandekerckhove, J. Poesen. Economic Valuation of Landslide Damage in Hilly Regions: A Case Study from the Flemish Ardennes, Belgium. .Science of the total environment. 447C. 323-336. (2013)

7. D. Grabowski, P. Marciniec, T. Mrozek, P. Nescieruk, W. Rączkowski, A. Wójcik, Z. Zimnal, Instrukcja opracowania mapy osuwisk i terenów zagrożonych ruchami masowymi, Państwowy Instytut Geologiczny w Warszawie, Państwowy Instytut Geologiczny Oddział Karpacki w Krakowie (2008)

8. Ustawa z 23 marca 2003 roku o planowaniu i zagospodarowaniu przestrzennym (Dz.U. $2003 \mathrm{nr} 80$ poz. 717)

9. P. Hanus, A. Pęska-Siwik \& R. Szewczyk. Computers and Electronics in Agriculture, 144, p. 915. (2018)

10. www.wieliczka.eu

11. http://metadane.pgi.gov.pl

12. P. Hanus, P. Benduch \& A. Pęska-Siwik. Przegląd Geodezyjny 90/2, 24-27. (2018)

13. M. Mika, M. Siejka, P. Leń, Ż. Król . The concept of using the water cadastre databases components for the construction of multi-dimensional cadastre in Poland. Survey Review, (2016)

14. Rozporządzenie Ministra Środowiska $\mathrm{z}$ dnia 18 listopada 2016 r. w sprawie dokumentacji hydrogeologicznej i dokumentacji geologicznoinżynierskiej (Dz.U. z 2016 r. poz. 2033)

15. J. Mazurek, M. Cała. Górnictwo i Geoinżynieria. 35 : 433-440. (2011)

16. E. Jasińska. Real Estate Due Diligence On the Example of the Polish Market. 14th SGEM GeoConference on Informatics. Geoinformatics and Remote Sensing 2. SGEM2014 Conference Proceedings. June 19-25. 2014. Vol. 2. Bulgaria (2014)

17. M. Siejka, M. Mika, T. Salata \& P. Leń. Algorithm of land use spatial data processing for the local flood risk mapping, Survey Review (2017)

18. http://www.wieliczka.e-mpzp.pl/

19. J. Mazurek, M. Cała.: Opinia w sprawie zagrożenia osuwiskowego domu mieszkalnego w miejscowości Raciborsko 176 (przysiółek Zagrody). Maszynopis, niepublikowany. Katedra GBiG AGH. Kraków, (2010)

20. E. Jasińska. Land use efficiency on example of the transformation of rural properties. The 10th International Conference Environmental Engineering: selected papers: April 27-28. 2017. Vilnius. Lithuania. (2017) 
21. E. Jasińska, E. Preweda. Determining the cadastraltax areas for the real estate premises based on the model of qualitative and quantitative. 10th International Conference Environmental Engineering: selected papers: April 27-28, 2017, Vilnius, Lithuania (2017)

22. E. Jasińska, E. Preweda. Infrastruktura i ekologia terenów wiejskich 1/III, p. 31-40 (2012).

23. P. Hanus, E. Jasińska, E. Preweda. Analysis of the Accuracy of Determining the Coordinates Property Borders. (2014)

24. http://geoportal.pgi.gov.pl/SOPO/ 